\title{
Fifteen Advances in Service Innovation Studies
}

\author{
Faridah Djellal and Faïz Gallouj ${ }^{1}$
}

\section{Introduction}

Service Innovation Studies (SIS) is a relatively young field of research; its emergence can be dated back to the second half of the $80 \mathrm{~s}$ and early $90 \mathrm{~s}$. Its existence is the result of the convergence between two originally independent research trajectories. The first of these is the Service Studies trajectory, which concerns the rise of service activities and how this affects public policy and business management, and the second is that of Innovation Studies (IS), which seeks to provide policymakers and business managers with relevant tools for innovation management and support.

Despite its newness, the SIS research field is relatively prolific and has already given rise to a number of 'surveys' - a sign of maturity. Some of these surveys are devoted to innovation in services in general, and some are more specifically devoted to one particular (sectoral or thematic) aspect of innovation (see Gallouj and Djellal, 2015). Sectoral surveys include, for example, those devoted to innovation in hospitals, in public services in general, in tourism, or in logistics services. Thematic surveys include those devoted to service innovation typologies, servitization, New Services Development (NSD), innovation indicators, and the relationship between innovation and employment in services (see Appendix 1).

Carrying out our own survey of these surveys, our objective in this chapter is to compile a list of what we consider the 15 major advances made in the SIS field since its advent almost a quarter-century ago. It should be noted that Ben Martin (2015) has carried out a similar review of the top 20 advances in Innovation Studies in general since it first emerged almost 50 years ago (see Appendix 2a). Paradoxically, while one of the most dramatic structural changes over the past half-century has been the rise of the tertiary sector to the detriment of the industrial and agricultural sectors, not one of the 20 major advances explicitly mentions services. Martin's review reflects the classic tendency of either underestimating innovation in services, or failing to consider it as distinct from industrial innovation (in accordance with the so-called assimilation perspective). It does not take into account advances made in this field since the $1990 \mathrm{~s}^{2}$.

Our survey of the advances made in SIS reflects an autonomization of SIS in relation to IS. These advances can be divided into two groups, which constitute the two main sections of the chapter. The first group (7 Advances) reflects changes in recognition of SIS, in the general theoretical perspectives favoured, and in understanding of the fundamental nature of service innovation. The second encompasses advances in innovation modes and advances in institutional and regulation arrangements. The eight Advances of this second group illustrate changes in theoretical perspectives (assimilation, demarcation, integration) within operational

\footnotetext{
${ }^{1}$ We would like to thank the editors and the reviewers of this book for their insightful comments that made it possible to improve our chapter.

${ }^{2}$ It should be noted, however, that Martin (2015) (implicitly or explicitly) incorporates certain issues related to innovation in services in his list of "Twenty challenges for innovation studies". This is in particular illustrated by the two following challenges: 1) "From visible innovation to "dark innovation"” and 2) "From innovation in manufacturing to innovation in services" (see Appendix 2b).
} 
fields (managerial, institutional or political), as well as tensions between these perspectives. Analysis of these 15 advances will make it possible, in our conclusion, to sketch out a certain number of knowledge gaps in SIS as well as a certain number of research challenges to be addressed in the future.

\section{Advances in the recognition of SIS and in the general theoretical perspectives adopted}

Like many other fields of economic theory, Innovation Economics was built in the manufacturing field. Economic analysis has long considered that services are not concerned by the innovation issue, insofar as services either do not innovate, or do so only to a negligible extent. The conquest of Innovation Studies (IS) by services has been gradual. It is possible to account for the progressive recognition of SIS (and its growing legitimacy) through successive changes reflecting advances in general theoretical perspectives (see Table $1)$.

\section{Table 1: Fifteen Advances in Service Innovation Studies}

- Advances in the recognition of SIS, in general theoretical perspectives and in understanding of the nature of innovation

1. From non-innovative services to services as simple adopters of technological innovations

2. From services as simple passive adopters to services as active adopters - and even producers of technological innovations

3. From services as adopters/producers of technological innovation to services as producers of specific innovation forms

4. From innovation in certain specific service sub-sectors to innovation across all service activities

5. From innovation in services to innovation through services

6. From innovation in services to service innovation (everywhere)

7. From publications in existing journals to the creation of specialized journals

- Advances in innovation operating modes and institutional and regulation arrangements

8. From the 1992 edition of the Oslo Manual to the 2005 edition

9. From assimilation surveys to demarcation and integration surveys

10. From assimilation policies to demarcation and integration policies

11. From the search for productivity to the search for performance

12. From natural interactivity to linearization and back to interactivity

13. From services industrialization to goods servitization

14. Balancing the intrinsic tension between service standardization and service customization

15. Balancing the intrinsic tension between service extension and service regression

Advance 1. From non-innovative services to services as simple adopters of technological innovations

Following a phase of outright denial of existence, the first advance achieved by SIS was the recognition of a minimalist innovation activity, limited in both nature and source - one that is limited to the adoption of technical systems produced by the manufacturing sector. The technologies in question are those devoted to the transportation of information or material objects (ICTs, road, air, rail, sea transport systems, etc.). This advance illustrates a technologist and industrialist (or assimilationist) view of innovation (Gallouj, 1994, 2010; Coombs and Miles, 2000): just as in manufacturing, service innovation is primarily supposed to consist of a material artefact. Besides the exogenous dimension of technologies (only considered as service production factors), this advance also reflects the subordinate position of services to manufacturing. After all, services simply adopt (relatively passively, at this 
stage) innovative technologies produced in manufacturing sectors. Technological trajectories at work in services are therefore 'supplier-dominated' according to Pavitt's typology (1984).

\section{Advance 2. From services as simple passive adopters to services as "adapters" or active adopters - and even producers of technological innovations}

The second advance achieved by SIS is the shift from services as simple passive adopters to services as active adopters and even producers of technological innovations. Since innovation is still limited to technical systems, this vision remains technologist and industrialist or assimilationist. However a twofold trend of endogenization and autonomization of innovation dynamics in services is at work here: the endogenization of technologies (especially ICTs) means that they are no longer subject to simple passive adoption, but rather to more complex managerial mechanisms of integration or embedding in the organization. The innovative service is therefore a hybrid category combining information and communication technologies with organizational engineering. Autonomization, on the other hand, reflects the fact that service organizations can, in some cases, cease to depend on suppliers from manufacturing sectors, and produce their own innovative technical systems. In some cases, this autonomization (vis-a-vis the manufacturing sector) can even result in an inversion of the balance of power between manufacturing and services. Service providers may even dominate their industrial suppliers and orient their technological trajectories - for example by imposing functional and technical specifications for new products. Such 'customer-dominated' trajectories manifest themselves, for example, in large-scale retailing (where major retailers often dictate conditions to their industrial suppliers).

Advance 3. From services as adopters/producers of technological innovations to services as producers of specific forms of innovation (or from visible to invisible innovation)

The conceptions of innovation discussed in Advances 1 and 2 make it possible to grasp only the tip of the innovation-in-services iceberg (Figure 1). This visible part of innovation is the one perceived by such traditional indicators as R\&D and patents; it is limited to technological product and process innovations.

SIS highlights an innovation gap - namely the existence of invisible or hidden innovations. For this reason, Advance 3 entails concentrating on the submerged part of the innovation iceberg, and accounting for non-technological forms of innovation: intangible product and process innovations, organizational innovations, methodological innovations, marketing innovations, and so on. In so doing, this advance reflects a displacement of the analytical focus from visible to invisible (hidden or forgotten) innovation. It illustrates the transition from a technologist, industrialist or assimilationist perspective to a non-technologist, servicebased or demarcation perspective, i.e. a perspective focusing service specificities and invisible or hidden innovation (Gallouj, 1994, 2010; Coombs and Miles, 2000). It assumes that SIS will free itself of the conceptualizations inherited from an industrialist culture and begin unlocking the knowledge trap in which they are confined. It should be noted that, in his research agenda for IS, Ben Martin (2015) evokes the shift "from visible innovation to dark innovation" (see Appendix 2b). He does not, however, explicitly acknowledge what this progress in IS owes to SIS.

The non-technological character of these invisible innovations does not mean that they are not (or cannot be) based on material technologies (IT or telecommunications systems, or means of 
transportation, for example), but rather that they are not consubstantial to them, and can in some cases dispense with them.

Figure 1: The innovation iceberg (Source: Djellal and Gallouj, 2016)

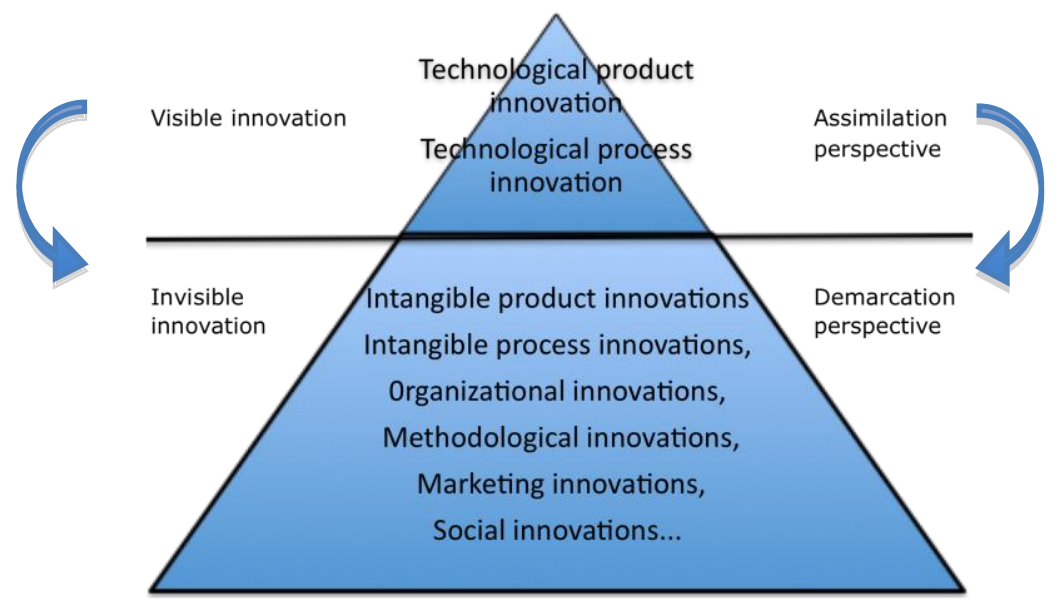

Advance 4. From innovation in certain specific sectors to innovation across all service activities

The search for the specificity of innovation in services was initially performed using 'knowledge intensive services' as a main field of investigation: Knowledge Intensive Business Services such as consultancy and engineering services as well as information services such as financial services (Gadrey et al., 1995; Miles et al., 1995; Gadrey and Gallouj, 1998). This empirical focus can be explained by several factors. First, knowledge intensive services are among the purest of the pure services in that they best meet those technical criteria that are supposed to distinguish services from goods (Zeithaml et al., 1985): intangibility, heterogeneity, inseparability (of production and consumption) and perishability (non-stockability). This 'purity' is clearly an asset in seeking to identify the specificities of services innovation (related to the fundamental nature of these activities). Second, these services are both knowledge and information intensive, making them inherently extrasensitive and open to innovation issues.

The question of the specificity of the forms of innovation has however spread rapidly to many other empirical investigation fields. These include: transportation, trade, cleaning, hospitality, tourism (Sundbo et al. 2007), health ${ }^{3}$, public services (Fuglsang, 2008; Scupola and Zanfei, 2016), etc.

\section{Advance 5. From innovation in services to innovation through services}

One major advance in SIS is recognition of the key role played by Knowledge Intensive Business Services (consultancy in its various professional or technological forms, engineering, R\&D) in their clients' innovation dynamics (especially industrial clients). Not only are Knowledge Intensive Business Services (KIBS) the most innovative service sector and the

\footnotetext{
${ }^{3}$ Innovation in non-healthcare peripheral services (e.g., catering, hospitality, cleaning, trade, etc.) is being addressed in this case, rather than biomedical and pharmacological innovation (which is characterized by a longstanding and abundant literature).
} 
main sector addressed by SIS (see Advance $\mathrm{n}^{\circ} 4$ ), but, as knowledge-processing and knowledge-producing machines, they also support innovation activities in other organizations (Miles et al., 1985; den Hertog and Bilderbeek, 2000; Gallouj, 2002b). In addition to playing the industrial innovation facilitator and industrial innovation diffuser roles, they also take on the role of sub-contractor (or co-producer) in this innovation. Recognition by SIS of the role played by KIBS reflects the shift from the recognition of innovation in services to the recognition of innovation through services.

This essential relationship (innovation through services) can be considered at micro or macro level. At micro level, the literature describes the existence of an interactional model of innovation (Gallouj, 2002b) that complements the traditional Schumpeterian entrepreneurial and monopolistic models (Schumpeter Mark 1 vs. Schumpeter Mark 2), in which the individual entrepreneur and the $\mathrm{R} \& \mathrm{D}$ department respectively embody the entrepreneurial spirit. In the interactional model (sometimes anachronistically labelled Schumpeter Mark 3), this spirit is embedded in the external service providers (KIBS). At macroeconomic level, already-dated European statistical analyses underline a strong correlation between the share of KIBS in total employment, and national performance in terms of innovation (European Commission, 2008). The theoretical perspective illustrated by this recognition of KIBS' role in innovation dynamics is called inversion (Gallouj, 2010). It reflects an inversion of the balance of power (in terms of innovation) between manufacturing and services.

\section{Advance 6. From innovation in services to service innovation (everywhere)}

The most advanced theoretical progress consists of replacing the opposition between goods and services with the idea that "all is service" and consequently, that everything is service innovation. There is therefore a shift from an assimilation/demarcation perspective to a synthesis or integration perspective (Gallouj, 1994, 2010; Coombs and Miles, 2000), in which the opposition of goods and services is set aside in a bid to develop unifying theoretical models capable of accounting for innovation in both goods and services, in all its forms (visible and invisible).

A number of theoretical frameworks have emerged that share the common assumption of a blurring of the boundaries between goods and services, thus suggesting integrative analyses of goods and services and innovation in goods and services. These frameworks include the functional economy (Stahel, 1997), which defines both goods and services by the function (service) they provide; the experience economy (Pine and Gilmore, 1999; Sundbo and Darmer, 2008; Sundbo and Sorensen, 2013), which defines them by the experience they provide to consumers, and the approach in terms of characteristics developed by Gallouj and Weinstein (1997) (see also de Vries, 2006; Garcia-Windrum and Goñi, 2008), which defines any goods or services as the implementation of competence and technical characteristics in order to produce service characteristics (utilities or use values). In this latter approach, innovation and its various modalities are defined by action on characteristics (their addition, deletion, association, dissociation or formatting).

Of the more recent integrative approaches, which are very popular, two closely linked approaches are noteworthy: "Service-Dominant Logic" (Vargo and Lusch, 2004; Lusch and Vargo, 2006), which defines value by value-in-use, blurring the difference between goods and services, and the new "service science" perspective (Maglio and Spohrer, 2008), which is a science of both services and goods. There is thus a shift from a situation in which science was 
not interested in services and service innovation, to one in which there is a perceived need to develop a (multidisciplinary) "service science".

\section{Advance 7. From publications in existing reviews to the creation of specialized reviews}

Important early works on innovation in services were published in general management and innovation management journals, as well as in industrial and innovation economics journals. The journal Research Policy in particular has published a number of seminal articles in this field (including the pioneering work of Barras) ${ }^{4}$. The publication of scientific journals specializing in services is one of the important advances in SIS, and testifies to their growing legitimacy. Table 3 provides a list of these journals, indicating their dates of creation and editors. The table does not take into account a certain number of journals that cover specific services sub-sectors - e.g., health services, tourism, transportation and logistics, etc.

Table 3: List of scientific journals in the field of services economics and management

\begin{tabular}{|c|c|c|}
\hline Journal & $\begin{array}{c}\text { Creation } \\
\text { date }\end{array}$ & Publisher \\
\hline Economia dei Servizi: Mercati, Istituzioni e Management & 2006 & Il Muliano \\
\hline Economia e diritto del terziario & 1991 & FrancoAngeli \\
\hline $\begin{array}{c}\text { European Review of Services Economics and } \\
\text { Management (ERSEM) (replacing Economies et Sociétés, } \\
\text { EGS series) }\end{array}$ & $\begin{array}{l}2016 \\
1995\end{array}$ & $\begin{array}{l}\text { Les Classiques Garnier } \\
\text { Les presses de l'Isméa }\end{array}$ \\
\hline e-Service Journal & 2001 & Indiana University Press \\
\hline $\begin{array}{c}\text { International Journal of Service Science, Management, } \\
\text { Engineering, and Technology (IJSSMET) }\end{array}$ & 2010 & IGI Global \\
\hline $\begin{array}{l}\text { International Journal of Services, Economics and } \\
\text { Management (IJSEM) }\end{array}$ & 2009 & Inderscience \\
\hline $\begin{array}{c}\text { International Journal of Services and Operations } \\
\text { Management (IJSOM) }\end{array}$ & 2005 & Inderscience \\
\hline $\begin{array}{c}\text { International Journal of Services Operations and } \\
\text { Informatics (IJSOI) }\end{array}$ & 2006 & Inderscience \\
\hline International Journal of Services Sciences (IJSSci) & 2008 & Inderscience \\
\hline $\begin{array}{c}\text { International Journal of Services Technology and } \\
\text { Management (IJSTM) }\end{array}$ & 2000 & Inderscience \\
\hline $\begin{array}{l}\text { Journal of advanced Research in Service Management } \\
\text { (JoARSM) }\end{array}$ & 2014 & $\begin{array}{l}\text { Advanced Research (ADR) } \\
\text { Publications (India) }\end{array}$ \\
\hline $\begin{array}{c}\text { Journal of Service Management (JOSM) } \\
\text { Formerly International Journal of Service Industry } \\
\text { Management }\end{array}$ & $\begin{array}{l}2009 \\
1990\end{array}$ & Emerald \\
\hline Journal of Service Research (JSR) & 1998 & Sage \\
\hline Journal of Service Science Research (JoSSR) & 2009 & Springer \\
\hline Journal of Service Science (JSS) & 2008 & The Clute Institute \\
\hline Journal of Service Science and Management (JSSM) & 2008 & Scientific Research \\
\hline Journal of Services Marketing (JSM) & 1987 & Emerald \\
\hline $\begin{array}{l}\text { Journal of Service Theory and Practice, } \\
\text { Previously published as Managing Service Quality }\end{array}$ & $\begin{array}{l}2015 \\
1991 \\
\end{array}$ & Emerald \\
\hline $\begin{array}{l}\text { Manufacturing and Service Operations Management } \\
\text { (MSOM) }\end{array}$ & 1999 & Informs \\
\hline Service Business & 2007 & Springer \\
\hline Service Management & 2005 & $\begin{array}{l}\text { Scientific Journal of University of } \\
\text { Szczecin (Poland) }\end{array}$ \\
\hline
\end{tabular}

\footnotetext{
${ }^{4}$ Of the 43 reference articles in the field of SIS included in the book published by Gallouj and Djellal (2015), no fewer than 12 had originally been published in Research Policy.
} 


\begin{tabular}{|c|c|l|}
\hline Service Science & 2009 & Informs \\
\hline The Service Industries Journal & 1983 & Taylor \& Francis \\
Formerly known as Service Industries Review & 1981 & \\
\hline
\end{tabular}

\section{Advances in operative modes and corresponding institutional and regulation mechanisms}

The next eight advances concern the organizational modes and institutional environment of service innovation (see Table 1). These advances form part of two separate groups; the first includes advances expressing the shift from one state to another, while the second (which includes only two cases) brings together advances that involve a dialectic relationship (tension, confrontation and balance) between two opposite states. For operational fields (managerial, institutional or political), these advances mainly illustrate either changes in theoretical perspectives (assimilation, demarcation, integration) or tensions between these perspectives.

\section{Advance 8. From the 1992 edition of the Oslo Manual to the 2005 edition}

The theoretical advances outlined above have brought about significant institutional advances. Thus, the Oslo Manual published by the OECD, which sets international conventions for the definition and measurement of innovation (mainly in order to homogenize national surveys) has undergone several revisions, keeping pace with theoretical advances in SIS and the rise of their legitimacy. The first version (OECD, 1992) illustrates the ignorance (or denial) phase of the service innovation issue. Indeed, the guidelines suggested in this version address only manufacturing activities, explicitly excluding market and public services.

The revised version (OECD, 1997) includes market services in its target, yet takes only technological product and process innovations into account. It therefore falls within the scope of the theoretical perspective we have labelled technologist and industrialist or assimilationist. A major institutional advance was made in 2005 (OECD, 2005) in that - mainly in order to take into account the specificities of services in a service-based/demarcation and integrative ${ }^{5}$ perspective - the manual henceforth also recognizes certain forms of non-technological innovation, namely marketing and organizational.

These institutional advances, arising out of theoretical and empirical advances in SIS, have in turn driven a powerful dynamic of empirical research in this area (see Advance 9).

\section{Advance 9. From assimilation surveys to demarcative and integrative surveys}

These same institutional advances have also led to advances in surveys devoted to innovation in services. Thus (again as part of the shift from assimilation to demarcation and integration theoretical perspectives) assimilationist surveys have given way to demarcative and integrative surveys. Assimilationist or 'subordinate' surveys (Djellal and Gallouj, 1999) simply apply to services questionnaires that were designed for manufacturing and are focused on technological innovation. Usually, these reflect a simple transposition to services of the OECD Oslo Manual guidelines (1992 version) that were developed to provide definitions of technological innovation in manufacturing. Demarcative or 'autonomous' surveys, however, are based on definitions and questionnaires developed to address specific forms of innovation in services (see Djellal and Gallouj, 1999 for examples).

\footnotetext{
${ }^{5}$ Indeed, the new forms of non-technological innovation introduced concern both manufacturing and services.
} 
Questionnaires designed on the basis of the latest revision of the Oslo Manual (OECD, 2005) can be considered integrative surveys, insofar as they apply the same innovation indicators to both goods and services. As we have already outlined, this is a demarcative integration in that new types of non-technological innovation (organizational and marketing) are introduced to address innovation in goods and services in a fresh way.

General lessons to be drawn from community innovation surveys carried out on the basis of these last conventions include the following:

- Performance of services in terms of innovation is significant. The myth of services as stragglers in terms of innovation is questioned.

- Some service sectors are even more innovative than manufacturing sectors. This is the case with KIBS in general and among them especially with ICT and engineering KIBS.

- Organizational and marketing (non-technological) innovations occupy an important position in services - often more important than in manufacturing.

- The introduction of new services is not restricted to the services sector. All economic sectors are capable of introducing such innovation types.

\section{Advance 10. From assimilation policy to demarcation and integration policy}

Advances in terms of public policies designed to support innovation in services have naturally followed the same path as theoretical perspectives, ranging from assimilation to demarcation and integration (Rubalcaba, 2006). It should be noted that these advances more often reflect an evolution of theoretical consciousness than concrete political achievements. Thus, public actions in support of innovation in services initially favoured an assimilationist (and technological) perspective: they were content to apply industrial (mainly scientific and technical) policy to services. Because these policies are inadequate, it is necessary to implement differentiation or demarcation policies that take into account the specificities of services, namely: i) the often-interactive dimension of their product (and thus of their innovation) and the difficulty of distinguishing between product, process and organization; ii) less $R \& D$ activity than in manufacturing, and of a very particular nature; iii) less visible results of innovation, due to the immaterial dimension of the service; iv) higher uncertainty and risk levels and stronger market failures; v) difficulty of appropriation of innovation and ease of imitation. Finally, given the convergence between goods and services, integrative innovation policies are emerging. These are specifically aimed at promoting "Product-Service Systems" (see Advance 13) while supporting both the tangible and intangible dimensions of innovation strategies in service companies.

\section{Advance 11. From the search for productivity to the search for performance}

The productivity issue in services has been addressed in three ways, reflecting the three stages in the evolution of theoretical thinking and managerial, institutional and policy practices.

The first stage was the observation of low productivity in services. This finding was expressed in particular in pioneering studies by Clark (1940) and Fourastié (1949), and results in consideration of low productivity as an intrinsic characteristic constituting the criterion for defining services in a positive way in order to distinguish them from the other two sectors themselves, conversely, characterized by a higher productivity growth rate. This conception of stagnant services (given their low technology intensity and low productivity growth rate) lies at the heart of Baumol's unbalanced growth model (Baumol, 1967; Baumol et al., 1985). 
The second stage was to challenge the idea of the naturalness of low services productivity. This challenge is based on two arguments, one methodological and the other managerial (Djellal and Gallouj, 2008). The managerial argument highlights the systematic (and often effective) implementation of productivity growth strategies across all service companies and organizations, whether public or private. The search for productivity gains (particularly through standardization and industrialization of the service, and the use of technical systems) has long been considered a strategic imperative in many service organizations (Levitt, 1976). The methodological argument, however, consists of questioning productivity measurement methods, which face the difficulty of defining output and measuring it in volume. In the latter case, the hypothesis is that measurement of productivity in services is flawed; it is probably underestimated and in all cases different from what is measured by manufacturing-biased indicators and methods.

The third stage suggested that productivity measurement (an industrialist concept) be replaced by multi-criteria performance assessment, along with the growth mantra (GDP) giving way to a sustainable development and growth of well-being approach (GDH - Gross Domestic Happiness). For example, convention theory (Boltanski and Thévenot, 1991) offers an interesting heuristic framework for addressing the question of the definition and justification of products and performance in a pluralistic way. It makes a distinction between the industrial world (of volumes and technical operations) and other worlds preferring other value definition and justification systems. These include the following spheres:

- the world of market and finance (favouring monetary and financial values)

- the relational and domestic world (favouring interpersonal, empathic and trusting relationships consolidated over time). This a world that gives central importance in product evaluation to the quality of relationships)

- the civic world (that of social relationships based on concern for equal treatment, fairness and justice)

The performance of an organization or a nation can be assessed according to these different worlds, which may be complementary or competitive.

\section{Advance 12. From natural interactivity to linearization, and back to interactivity}

Within the field of IS, Ben Martin (2015) considers the shift "from the linear model to the interactive model" of innovation to be a major advance in theoretical analysis and corporate practices. The linear model describes a planned and systematic innovation process that sequentially connects the $\mathrm{R} \& \mathrm{D}$, production and marketing phases. It is often associated with well-formalized, specialized and fairly closed innovation structures. This linear model struggles to respond quickly to the dynamics of a turbulent environment. It is often replaced (in company organization, as well as in theoretical debate) by a more flexible, interactive and open model of innovation - recently popularized by the fashionable open innovation concept (Chesbrough, 2003).

This change in both management practices and theoretical approach (underlined by Ben Martin in his survey of the main advances in IS) does not apply to services homothetically. First, those R\&D activities constituting the initial phase of the linear model are rare in services. Second, the first empirical works devoted to the organization modes of innovation in services converged on the pre-eminence of flexible, loosely-coupled, less-programmed and less-institutionalized innovation processes (Sundbo and Gallouj, 2000; Sundbo, 1997). Above 
all, it appears that services are interactive and open by nature insofar as they place the consumer (who is, in many cases, a co-producer of the service and/or a stakeholder in innovation) centre stage.

Given these findings, initial observations are that in service organizations, efforts are triggered by linearization of production and innovation models and, in managerial sciences, by recommendations in favour of linearization strategies. In the field of production, this linearization is synonymous with industrialization (see Advance 13). In the field of innovation, linearization is illustrated by implementation of NSD models (Scheuing and Johnson 1989, Easingwood 1986, De Brentani 1989, Edvardsson and Olsson 1996), inspired by New Product Development (NPD) models, which provide very precise methodologies for the design and production of new goods.

However, though it continues to spark the interest of researchers in management science, this linearization is increasingly challenged by interactivity, co-production and opening up, which seem - as we have already pointed out - to be natural technical characteristics of services. It is, therefore, irrelevant to state that SIS has shifted from the linear innovation model to the interactive innovation model - rather, it has shifted from linearization efforts (again within an assimilationist perspective) to the recognition and strengthening of an existing natural reality: interactivity, coupled with smooth and flexible openness.

This interactivity and openness encompasses a wide variety of different cooperative models (internally and/or externally) that are more or less sophisticated and/or formalized.

These include a number of unplanned or emerging models (rapid application, practice-based, bricolage innovation and ad hoc innovation) characterized by being closely linked to learning dynamics (learning by doing, using or interacting). These micro-models (not detailed here: see Toivonen and Tuominen, 2009; Gallouj and Weinstein, 1997; Fuglsang, 2010; Toivonen, 2010 and Fuglsang and Sørensen, 2011) describe various 'mechanisms' at work within organizations, resulting in incremental innovations related to the dynamics of internal or external change.

At different analytical levels, open innovation also encompasses innovation dynamics in interaction with customers and users, consultants, and multiple partners within innovation networks or systems (Sundbo and Fuglsang, 2002; Sundbo and Toivonen, 2012; Gallouj et al., 2013, Westh Nicolajsen and Scupola, 2011).

\section{Advance 13. From services industrialization to goods servitization}

The two contradictory processes of services industrialization and goods servitization have helped blur the distinction between goods and services in contemporary economies, where these two processes encompassing innovation dynamics historically follow one another. Indeed, within the basic principle of assimilation to the dominant economic and theoretical models, service companies and organizations have made efforts to industrialize, making their product more material and less blurred. The process of goods servitization, which reflects the rise (in various forms) of the service logic in the supply of manufacturing companies, appeared later. This time lag is what is expressed by the idea of a shift from services 
industrialization to goods servitization. However one process does not replace the other; in contemporary economies, industrialization and servitization coexist ${ }^{6}$.

The industrialization of services is a well-established trend accurately described by Levitt (1976), who defined it as a strategic imperative for service companies. Part of the assimilation perspective (assimilation of services to goods), it is based on increasing mechanization, the application of industrial production methods (Taylorism, Fordism), the addition of goods to services $^{7}$ and the search for productivity gains. It is a genuine "natural trajectory" within the meaning of evolutionary theory (that is, a trajectory that applies to many, if not all, sectors). This trajectory is powerful insofar as it is still at work today - mainly in the implementation of low-cost business models across a growing number of service sectors.

Goods servitization is a generic strategy aimed at transforming the supply of goods into service delivery, via different (and more or less mature) modes. It therefore encompasses the following modes, whose relationships to the innovation issue are obvious:

1) The (mechanical) addition of services to a supply of goods, in order to differentiate it and build its quality (Furrer, 2010). The addition of pre-sales and after-sales services (on which the success of Fordist economies was based) is thus a longstanding servitization modality.

2) The simultaneous (though not necessarily integrated) offer of goods and services by manufacturing companies, rendering iconic industrial companies (especially in IT) ${ }^{8}$ as primarily service providers - since the major part of their turnover and profit now comes from the sale of services.

3) The rise of integrated "product-services" offers referred to in the literature by a variety of terms ${ }^{9}$ : complex packages or compacks (Bressand and Nicolaidis, 1988), Product-Service Systems (Goedkoop et al., 1999; Mont, 2000), Product-Service Bundles (Vandermerwe and Rada; 1988. Stremersch et al, 2001), (customers) solutions (Matthyssens and Vandenbempt, 2008; Evanschitzky et al., 2011, Bonney et al., 2009), hybrid products (Shankar et al., 2009), hybrid solutions, hybrid offerings (Ulaga and Reinartz, 2011), hybrid innovations (Shankar et al., 2007)...

4) The change in the consumer's use or consumption mode of the goods, combined with a change in the producer's business model. The company no longer provides goods, and the consumer no longer acquires ownership of goods, yet both respectively sell and buy the use of the goods and the service they provide. From this perspective, then, it is no longer cars, copiers, or machines that are sold, but rather miles travelled, number of photocopies made, operational hours, etc.

The industrialization of services is an assimilationist modality of innovation in services, whereas the servitization of goods is a generic (integrative) modality that places service innovation at the heart of industrial innovation dynamics. Indeed, within servitization, service

\footnotetext{
${ }^{6}$ Although both dynamics coexist, we do not describe this advance in terms of reconciliation or balancing of tensions, as we did for Advances 14 \& 15. Indeed, we consider that in order to be the object of a balancing process, a tension must relate to the same reality (services) - not the case with Advance 13, which describes a reverse dynamics in goods and services.

${ }^{7}$ It should be noted that the addition of goods to services contributes to the industrialization of services, while the addition of services to goods falls within the scope of the goods servitization process. These are two different ways of building Products-Services Systems.

${ }^{8}$ IBM and Benetton have long been cited as archetypes of this trend, which has spread to many manufacturing companies.

${ }^{9}$ These references are only intended to illustrate the variety of terminologies used to describe the same economic reality. They do not necessarily indicate the alleged primary user of each concept discussed.
} 
innovation becomes central to manufacturing companies and sectors; it is a key source of competitive edge.

\section{Advance 14. Balancing the "intrinsic tension" between service standardization and service customization}

The advances we look at from this point on involve the search for a balance between two states (or dynamics) in tension within an organization, sector or whole economy, rather than a transition from one situation to another.

The 14th advance we address reconciles (establishes a balance within) the intrinsic tension between industrialization/standardization of the service and its customization, that is, between repetition and personalization (Sundbo, 1994, 2002). Indeed, while industrialization/standardization aims to erase the specificities of the service in order to provide a homogeneous service (a quasi-product), customization emphasizes diversity, striving to offer a particular service that is tailored to the customer's specificities.

Taken separately, these two processes are important innovation trajectories in services. Yet fresh innovation potential is provided by the reconciliation of these trajectories within a single company or sector. The assimilation-demarcation-integration paradigm can once again be applied here. A company's implementation of an industrialization strategy for its service offering (McDonald's, for example) falls within the scope of an assimilation perspective. Customization strategies, however, fit into the demarcation perspective. Finally, an integration perspective is at work when a single organization mobilizes both strategies, thus reconciling industrialization/standardization and customization (Djellal and Gallouj, 2008). Banks, for example, through their multi-channel offers, manage to reconcile standardized quasi-products, automated self-service and customized high value-added services. At the sectoral level, this reconciliation of (balance between) standardization/customization can be illustrated by the development of boutique hotels, on the one hand, and the development of national or international hotel chains, on the other.

\section{Advance 15. Balancing the intrinsic tension between service extension and service regression}

Another important advance in SIS is recognition of the idea that innovation can originate not only in the extension/complexity of a service - but also in its regression. This tension between two opposing basic principles is not independent of the previous tension (between standardization and customization, and based on reorganization of the service offering) - yet this new tension assumes positive or negative development of the range of services offered.

At the theoretical level, this advance in innovation modes is based on an old idea developed in the field of services marketing, according to which the service consists of one or more central services associated with a certain number of peripheral services (Lovelock, 1991). In the field of economics, it is also based on the Lancasterian approach of seeing the product as a combination of services characteristics (Gallouj and Weinstein, 1997). In both conceptions, innovation may stem not just from the addition of services (or services characteristics), but also from the elimination of services (or services characteristics). This paradoxical idea - that innovation can also come from service regression - is of course illustrated by the low-cost services developing across all services sectors (air transportation, fast food, hard discount, etc.). 


\section{Conclusion}

The major advances in SIS addressed in this chapter have mainly concerned the recognition of innovation in services (its legitimization as a research object), its definition, organization and implementation, its measurement, and the institutional support mechanisms designed to promote it. It can be said that SIS is now sufficiently structured, as a research field, to lay claim to an autonomous existence in relation to the wider, more mature field of Innovation Studies of which it has hitherto been considered part.

While there has been undeniable progress in the field of SIS, many challenges remain, and these are part of a promising research agenda. These challenges were identified and discussed in a recent survey (Gallouj and Djellal, 2018) and can be divided into three groups: societal challenges, organizational and structural challenges, methodological and didactic challenges.

Societal challenges raise the question of the relationship between service innovation and a number of major societal questions, which we settle for listing here: environmental, social inclusion, development, religion, gender and ethical issues. Organizational and structural challenges call into question the relationship of service innovation to the problems of entrepreneurship, employment and qualification, as well as the dynamics of networking and systems. Lastly, methodological and didactic challenges raise further epistemological questions:

Which new service activities or sectors should be considered to pursue research on innovation in services?

What research methods should be preferred?

What are the new measurement and evaluation challenges?

What are the relationships between research on innovation in services and education within this field?

\section{Bibliography}

Agarwal, R., Selen, W., Roos, G., Green, R. (2015) The handbook of service innovation, Springer.

Alam, I. and Perry, C. (2002), 'A customer-oriented new service development process', Journal of Services Marketing, 16 (6), 515-534.

Arduini, D. and Zanfei, A. (2014), 'An overview of scholarly research on public e-services? A meta-analysis of the literature', Telecommunications Policy, 38 (5-6), 476-95.

Baines, T.S., Lightfoot, H.W., Benedettini, O. and Kay, J.M. (2009), 'The servitization of manufacturing: a review of literature and reflection of future challenges', Journal of Manufacturing Technology Management, 20 (5), 547-67.

Baumol, W.J. (1967), 'Macroeconomics of unbalanced growth', American Economic Review, 57 (2), 415-426.

Baumol, W.J., Blackman, S.A.B., and Wolff, E.N. (1985), 'Unbalanced Growth Revisited: Asymptotic Stagnancy and New Evidence', American Economic Review, 75 (4), 806-817.

Boltanski Luc et Thévenot Laurent (1991), De la Justification. Les économies de la grandeur, Paris, Gallimard.

Bonney, F.L. and Williams, B.C. (2009), 'From products to solutions: the role of salesperson opportunity recognition', European Journal of Marketing, 43 (7/8), 1032-1052.

Bressand, A. and Nicolaïdis, K. (1988), 'Les services au cœur de l'économie relationnelle', Revue d'économie industrielle, 48 (1), 141-163. 
Bryson, J. R. and Monnoyer, M.-C. (2004), 'Understanding the relationship between services and innovation: the RESER review of the European service literature on innovation, 2002', The Services Industries Journal, 24 (1), 205-222.

Carlborg, P., Kindström, D. and Kowalkowski, C. (2014), 'The evolution of service innovation research: A critical review and synthesis', The Service Industries Journal, 34 (5), 373-398.

Chapman, R.L., Soosay, C. and Kandampully, J. (2003), 'Innovation in logistic services and the new business model: a conceptual framework', International Journal of Physical Distribution and Logistics Management, 33 (7), 630-50.

Chesbrough, H. (2003), Open Innovation: The New Imperative for Creating and Profiting from Technology, Cambridge, MA: Harvard Business School Press.

Clark, C. (1940), The Conditions of Economic Progress, Macmillan, London.

Coombs, R. and Miles, I. (2000), 'Innovation, Measurement and Services: The New Problematique', in Metcalfe, J.S. and Miles, I. (eds), Innovation Systems in the Service Economy: Measurement and Case Study Analysis, Dordrecht: Kluwer Academic Publisher, pp. 85-103.

De Brentani, U. (1989), 'Success and failure in new industrial services', Journal of Product Innovation Management, 6 (4), p. 239-258.

De Jong, J.P.J. and Vermeulen, P.A.M. (2003), 'Organizing successful new service development: a literature review', Management Decision, 41 (9), 844-858.

De Vries, E. J. (2006), 'Innovation in Services in Networks of Organizations and in the Distribution of Services', Research Policy, 35 (7), 1037-1051.

Den Hertog, P. and Bilderbeek, R. (2000), 'The new knowledge infrastructure: the role of technology-based knowledge intensive business services in national innovation systems', in Boden, M. and Miles, I. (eds), Services and the knowledge-based economy, London and New York: Continuum, pp. 222-246.

Djellal, F. and Gallouj, F. (1999), 'Services and the Search for Relevant Innovation Indicators. A Review of National and International Surveys', Science and Public Policy, 26 (4), 218 232.

Djellal, F. and Gallouj, F. (1999), 'Services and the search for relevant innovation indicators: a review of national and international surveys', Science and Public Policy, 26 (4), 218-32.

Djellal, F. and Gallouj, F. (2007a), 'Innovation in hospitals: a survey of the literature', European Journal of Health Economics, 8 (3), 181-93.

Djellal, F. and Gallouj, F. (2007b), 'Innovation and Employment Effects in Services: a Review of the Literature and an Agenda for Research', The Service Industries Journal, April, 27 (3-4), 193-213.

Djellal, F. and Gallouj, F. (2008), Measuring and improving productivity in services: issues, strategies and challenges, Cheltenham, UK and Northampton, USA: Edward Elgar Publishing.

Djellal, F. and Gallouj, F. (2016), 'Taking into account hidden innovation in innovation network: the role of public-private innovation networks in services' in Castro Spila, J., Echeverría J. and Unceta, A. (ed), Hidden Innovations: Concepts, Sectors and Case Studies, Donostia, Spain: Sinnergiak, pp. 39-54.

Djellal, F., Gallouj, F. and Miles, I. (2013), 'Two decades of research on innovation in services: which place for public services?', Structural Change and Economic Dynamics, 27, December, 98-117.

Drejer, I. (2004), 'Identifying Innovation in Surveys of Services: A Schumpeterian Perspective', Research Policy, 33 (3), 551-562.

Droege, H., Hildebrand, D. and Heras Forcada, M. (2009), 'Innovation in services: present findings, and future pathways, Journal of Service Management, 20 (2), 131-155. 
Easingwood, C. J. (1986), 'New product development for service companies', Journal of Product Innovation Management, 3 (4), 264-275.

Edvardsson, B. (1997), 'Quality in New Service Development: Key concepts and a frame of reference', International Journal of Production Economics, 52 (1-2), 31-46.

Edvardsson, B. and Olsson, J. (1996), 'Key concepts for new service development', The Services Industries Journal, 16 (2), 140-164.

European Commission (2008), European innovation scoreboard.

European Commission (2012), 'The 2012 Ageing Report: Economic and budgetary projections for the 27 EU Member States (2010-2060)', Directorate-General for Economic and Financial Affairs, Brussels.

Evangelista, R. and Sirilli, G. (1995), 'Measuring innovation in services', Research Evaluation, 5 (3), 207-15.

Evanschitzky, H., Wangenheim, F.V., and Woisetschläger, D.M. (2011), 'Service \& solution innovation: Overview and research agenda', Industrial Marketing Management, 40 (5), 657-660.

Fourastié, J. (1949), Le grand espoir du XX siècle, Paris: Presse Universitaire de France.

Fuglsang, L. (2008), 'Capturing the benefits of open innovation in public innovation: a case study', International Journal of Services Technology and Management, 9 (3-4), 234-248.

Fuglsang, L. (2010), 'Bricolage and invisible innovation in public service innovation', Journal of Innovation Economics and Management, 2010/1, n5, p. 67-87.

Fuglsang, L. and Sørensen, F. (2011), 'The balance between bricolage and innovation: Management dilemmas in sustainable public innovation', The Service Industries Journal, 31 (4), 581-595.

Furrer, O. (2010), 'A customer relationship typology of product services strategies', in Gallouj, F. and Djellal, F. (eds), The Handbook of Innovation and Services. A MultiDisciplinary Approach, Cheltenham, UK, Northampton, USA: Edward Elgar, pp. 679-721.

Gadrey, J. and Gallouj, F. (1998), 'The provider-customer interface in business and professional services', The Service Industries Journal, 18 (2), 1-15.

Gadrey, J., Gallouj, F. and Weinstein, O. (1995), 'New modes of innovation: how services benefit industry', International Journal of Service Industry Management, 6 (3), 4-16.

Gallouj F., Djellal F. (eds) (2018), A research agenda for service research, Cheltenham, UK, Northampton, USA: Edward Elgar Publishing (forthcoming)

Gallouj F., Rubalcaba L., Windrum P. (eds) (2013), Public-Private Innovation Networks in Services: the dynamics of cooperation in service innovation, Cheltenham, UK, Northampton, USA: Edward Elgar Publishing.

Gallouj, F. (1994), Economie de l'innovation dans les services [Economics of innovation in services], Paris: Editions L'Harmattan, Logiques économiques.

Gallouj, F. (2002a), Innovation in Services. The New Wealth of Nations, Cheltenham, UK, Northampton, USA: Edward Elgar Publishing.

Gallouj, F. (2002b), 'Interactional innovation: a neoschumpeterian model', in Sundbo, J. and Fuglsang, L. (eds), Innovation as strategic reflexivity, London, New York: Routledge, pp. 29-56.

Gallouj, F. (2010), 'Services innovation: assimilation, differentiation, inversion and integration', in Bidgoli, H. (ed.), The Handbook of Technology Management, Hoboken, NJ: John Wiley and Sons, 989-1000.

Gallouj, F. and Djellal, F. (2015), 'Introduction : services and innovation', in Gallouj, F. and Djellal, F. (eds), Services and Innovation, Cheltenham, UK, Northampton, USA: The International Library of Critical Writings in Economics series, Edward Elgar Publishers, pp. 5-20. 
Gallouj, F. and Djellal, F. (2015), Services and Innovation, Cheltenham, UK, Northampton, USA: The International Library of Critical Writings in Economics series, Edward Elgar Publishers.

Gallouj, F. and Djellal, F. (eds) (2010), The Handbook of Innovation and Services: $a$ multidisciplinary perspective, Cheltenham, UK, Northampton, USA: Edward Elgar Publishers.

Gallouj, F. and Savona, M. (2009), 'Innovation in Services. A Review of the Debate and a Research Agenda', Journal of Evolutionary Economics, 19 (2), 149-172.

Gallouj, F. and Savona, M. (2010), 'Towards a theory of innovation in services: a state of the art', in Gallouj, F. and Djellal, F. (eds) (2010), The Handbook of Innovation and Services: a multidisciplinary perspective, Cheltenham, UK, Northampton, USA: Edward Elgar Publishers, pp. 27-48.

Gallouj, F. and Weinstein, O. (1997), 'Innovation in Services', Research Policy, 26 (4-5), $537-556$.

Gallouj, F. and Windrum, P. (2009), 'Services and services innovation', Journal of Evolutionary Economics, 19 (2), 141-148.

Gallouj, F. and Zanfei, A. (2013), 'Innovation in public services: filling a gap in the literature', Structural Change and Economic Dynamics, 27, December, 89-'97.

Gault, F.D. (1998), 'Research and development in a service economy', Research Evaluation, 7 (2), 79-91.

Goedkoop, M.J., van Halen, C.J.G, te Riele, H.R.M. and Rommens, P.J.M. (1999), 'Product Service-Systems, ecological and economic basics', Report for Dutch Ministries of Environment (VROM) and Economic Affairs (EZ).

Greenhalgh, T., Robert, G., Macfarlane, F., Bate, P. and Kyriakidou, O. (2004), 'Diffusion of innovations in service organisations: systematic review and recommendations', Milbank Quarterly, 82 (4), 581-629.

Hjalager, A.-M. (2010), 'A review of innovation research in tourism', Tourism Management, 31 (1), 1-12.

Howells, J. (2007), 'Services and innovation: conceptual and theoretical perspectives', in Bryson, J. R. and P. W. Daniels (eds), The Handbook of Service Industries, Cheltenham, UK, Northampton, USA: Edward Elgar Publishing, pp. 34-44.

Howells, J. (2010), 'Services and innovation and service innovation', in Gallouj, F., Djellal, F. (eds) (2010), The Handbook of Innovation and Services: a multidisciplinary perspective, Cheltenham, UK, Northampton, USA: Edward Elgar Publishing, pp. 68-83.

Johne, A. and Storey, C. (1998), 'New service development: a review of the literature and annotated bibliography', European Journal of Marketing, 32 (3-4), 184-251.

Levitt, T. (1976), 'The industrialisation of service', Harvard Business Review, 54 (5), 63-74.

Lovelock, C. (1991), Services Marketing, Englewood Cliffs, NJ: Prentice-Hall.

Lusch, R. and Vargo, S. (2006), 'Service-dominant logic: reactions, reflections and refinements', Marketing Theory, 6 (3), p. 281-88.

Maglio, P.P. and Spohrer, J. (2008), 'Fundamentals of Service Science', Journal of the Academy of Marketing Science, 36 (1), March, 18-20.

Martin, B. (2015), Twenty challenges for innovation studies, SPRU Working Paper Series, SWPS 2015-30, November.

Matthyssens, P. and Vandenbempt, K. (2008), 'Moving from basic offerings to value added solutions: Strategies, barriers and alignment', Industrial Marketing Management, 37 (3), 316-328.

Miles, I. (2002), 'Service Innovation: Towards a Tertiarisation of Innovation Studies', in Gadrey, J. and Gallouj, F. (eds), Productivity, Innovation and Knowledge in Services, Cheltenham, UK, Northampton, USA: Edward Elgar Publishing, pp. 164-196. 
Miles, I. (2005), 'Innovation in services', in Fagerberg, J., Mowery, D. C. and Nelson, R. R. (eds.), The Oxford Handbook of Innovation, Oxford: Oxford University Press, pp. 433-458.

Miles, I. (2013), 'Public service innovation: what messages from the collision of innovation studies and services research', in Osborne, S.P. and Brown, L. (eds), Handbook of Innovation in Public Sector Services, Cheltenham, UK and Northmpton, MA, USA: Edward Elgar Publishing, pp. 72-88.

Miles, I., Kastrinos, N., Flanagan, K., Bilderbek, R., den Hertog, P., Huntink, W., Bouman, M. (1994), Knowledge-Intensive Business Services: Their Role as Users, Carriers and Sources of Innovation, PREST, University of Manchester.

Mont, O. (2000), Product Service-Systems, Final report, The International Institute of Industrial Environmental. Economics, Lund University.

OECD (1992), Oslo Manual: Guidelines for collecting and interpreting innovation data, $1^{\text {st }}$ Edition, Paris, OECD.

OECD (1997), Oslo Manual: Guidelines for collecting and interpreting innovation data, $2^{\text {nd }}$ Edition, Paris, OECD.

OECD (2005), Oslo Manual: Guidelines for collecting and interpreting innovation data, $3^{\text {rd }}$ Edition, Paris, OECD.

Pavitt, K. (1984), 'Sectoral Patterns of Technical Change: Towards a Taxonomy and a Theory, Research Policy, 13 (6), 343-374.

Pilat, D. (2001), 'Innovation and productivity in services: state of the art', in OECD (eds), Innovation and Productivity in Services, Paris: OECD, 17-54.

Pine, J. and Gilmore, J. (1999), The Experience Economy, Boston: Harvard Business School Press.

Rubalcaba, L. (2006), 'Which Policy for Innovation in Services?', Science and Public Policy, 33 (10), 745-56.

Rubalcaba, L., Michel, S., Brown, S.W. and Reynoso, J. (2012), 'Shaping, organizing, and rethinking service innovation: a multidimensional framework', Journal of Service Management, 23 (5), 696-715.

Scheuing, E.E. and E.M. Johnson (1989), 'A proposed model for new service development', Journal of Service Marketing, 3 (2), 25-35.

Scupola, A. and Zanfei, A. (2016),'Governance and innovation in public sector services: The case of digital library', Government Information Quarterly, 33 (2), 237-249.

Shankar, V, Berry, L. and Dotzel, T. (2007), 'Creating and Managing Hybrid Innovations', AMA Winter Educators' Conference, San Diego, CA, February 16-19.

Shankar, V., Berry, L. and Dotzel, T. (2009), 'A practical guide to combining products and services', Harvard Business Review, November, 94-99.

Snyder, H., Witell, L., Gustafsson, G., Fombelle, P. and Kristensson, K. (2016), 'Identifying categories of service innovation: A review and synthesis of the literature', Journal of Business Research, 69 (7), 2401-2408.

Stremersch, S. and Tellis, G. J. (2002), Strategic bundling of products and prices: A new synthesis for marketing, Journal of Marketing, 66 (1), 55-72.

Sundbo, J. (1994), 'Modulization of service production and a thesis of convergence between service and manufacturing organizations', Scandinavian Journal of Management, 10 (3), 245-266.

Sundbo, J. (1997), 'Management of innovation in services', The Service Industries Journal, 17 (3), 432-455.

Sundbo, J. (2002), 'The service economy: standardisation or customisation?', The Services Industries Journal, 22 (4), p. 93-116.

Sundbo, J. and Sorensen, F. (2013), Handbook on the Experience Economy, Cheltenham, UK, Northampton, USA: Edward Elgar Publishing. 
Sundbo, J. and Toivonen, M. (2012), User-based innovation in services, Cheltenham, UK, Northampton, USA: Edward Elgar Publishing.

Sundbo, J. Orfila-Sintes, F., Sørensen, F. (2007), 'The innovative behaviour of tourism firms: Comparative studies of Denmark and Spain', Research Policy, 36 (1), 88-106.

Sundbo, J., Darmer, P. (Eds) (2008), Creating experiences in the experience economy, Cheltenham, UK, Northampton, USA: Edward Elgar Publishing.

Sundbo, J., Fuglsang, L. (eds) (2002), Innovation as strategic reflexivity, Routledge.

Sundbo, J., Gallouj, F. (2000), Innovation as a loosely coupled system in services, International Journal of Services Technology and Management, 1(1), p. 15-36.

Toivonen, M. (2010), Different types of innovation processes in services and their organisational implications, in Gallouj, F. Djellal, F. (eds), The handbook of innovation and services, Edward Elgar, pp. 221-249.

Toivonen, M. and Caru, A. (2016), 'Prospects and policies in the development of knowledgeintensive business services in Europe', in Ferreira, J., Raposo, M., Fernandes, C. and Dejardin, M. (eds.), Knowledge Intensive Business and Regional Competitiveness, London and New York: Routledge, pp. 301-326.

Toivonen, M., and Tuominen, T. (2009). Emergence of innovations in Services, Service Industries Journal, 29 (7), 887-902.

Ulaga, W. and Reinartz, W.J. (2011), Hybrid Offerings: How Manufacturing Firms Combine Goods and Services Successfully, Journal of Marketing, 75 (6), 5-23.

Vandermerwe, S. and Rada, J. (1988), Servitization of Business: Adding Value by Adding Services, European Management Journal, 6 (4), 314-324.

Vargo, S.L and Lusch, R.F. (2004), Evolving to a New Dominant Logic for Marketing, Journal of Marketing, 68 (1), 1-17.

Westh Nicolajsen, H. and Scupola, A. (2011), 'Investigating issues and challenges for customer involvement in business services innovation', Journal of Business \& Industrial Marketing, 26 (5), 368-376.

Windrum, P. (2007), 'Innovation in Services', in Hanusch, H., Pyka, A. (eds), The Edward Elgar Companion to Neo-Schumpeterian Economics, Cheltenham, UK and Northampton, MA, USA: Edward Elgar, pp. 633-646.

Windrum, P. and Garçia- Goñi, M. (2008), A neo-Schumpeterian model of health services innovation, Research Policy, 37 (4), 649-672.

Windrum, P. and Koch, P. (2008), (eds), Innovation in Public Services: Entrepreneurship, Creativity and Management, Cheltenham, UK and Northampton, MA, USA: Edward Elgar.

Zeithaml, V.A., Parasuraman, A. and Berry, L.L. (1985), Problems and strategies in services marketing, Journal of Marketing, 49 (2), 33-46. 


\section{Appendix 1: General and specific literature surveys on innovation in services (non- exhaustive list) (enriched from Gallouj and Djellal, 2015)}

\begin{tabular}{|c|c|}
\hline \multicolumn{2}{|c|}{ General surveys } \\
\hline $\begin{array}{l}\text { - Droege et al. (2009) } \\
\text { - Bryson and Monnoyer }(2004) \\
\text { - Coombs and Miles }(2000) \\
\text { - Gallouj }(1994,2002 a, 2010) \\
\text { - Gallouj and Savona }(2009,2010) \\
\text { - Gallouj and Windrum }(2009) \\
\text { - Miles }(2002,2005)\end{array}$ & $\begin{array}{l}\text { - Gallouj and Djellal (2010) } \\
\text { - Howells (2007, 2010) } \\
\text { - Windrum (2007) } \\
\text { - Pilat (2001) } \\
\text { - Drejer (2004) } \\
\text { - Rubalcaba et al. (2012) } \\
\text { - Carlborg et al. (2014) } \\
\text { - Djellal and Gallouj (2015) } \\
\text { - Agarwal et al. (2015) }\end{array}$ \\
\hline \multicolumn{2}{|c|}{ Specific (sectoral) surveys } \\
\hline $\begin{array}{l}\text { - Innovation in hospitals } \\
\text { - Diffusion of innovation in health } \\
\text { services } \\
\text { - Miles et al. (1995) }\end{array}$ & $\begin{array}{l}\text { - Djellal and Gallouj (2007a) } \\
\text { - Greenhalgh et al. (2004) } \\
\text { - Den Hertog and Bilderbeek (2000) } \\
\text { - Toivonen and Caru (2016) }\end{array}$ \\
\hline - Innovation in public services & $\begin{array}{l}\text { - Djellal et al. (2013) } \\
\text { - Windrum and Koch (2008) } \\
\text { - Gallouj and Zanfei (2013) } \\
\text { - Miles (2013) } \\
\text { - Arduini and Zanfei (2014) }\end{array}$ \\
\hline - Innovation in Tourism & - Hjalager (2010), \\
\hline - Innovation in logistic services & - Chapman et al. (2003) \\
\hline \multicolumn{2}{|c|}{ Specific (thematic) surveys } \\
\hline - Typologies of innovation in services & - Snyder et al. (2016) \\
\hline - The servitization of manufacturing & - Baines et al. (2009) \\
\hline - New Services Development & $\begin{array}{l}\text { - De Jong and Vermeulen (2003), } \\
\text { - Johne and Storey (1998) } \\
\text { - Alam and Perry (2002) } \\
\text { - Edvardsson (1997) }\end{array}$ \\
\hline - Innovation indicators & $\begin{array}{l}\text { - Djellal and Gallouj (1999) } \\
\text { - Drejer (2004) } \\
\text { - Gault (1998) } \\
\text { - Evangelista and Sirilli (1995) }\end{array}$ \\
\hline - Innovation and employment & - Djellal and Gallouj (2007b) \\
\hline
\end{tabular}


Appendix 2:

a) Twenty Advances in Science Policy (Martin, 2015)

1. From individual entrepreneur to corporate innovators

2. From laissez faire to government intervention

3. From two factors of production to three

4. From single division to multidivisional effects

5. From technology adoption to innovation diffusion

6. From science push to demand pull?

7. From single factor to multi-factor explanations of innovation

8. From a static to a dynamic model of innovation

9. From the linear model to an interactive "chain-link" model

10. From one innovation process to several sector-specific types

11. From neoclassical to evolutionary economics

12. From neoclassical to new growth theory

13. From the optimising firm to the resource-based view of the firm

14. From individual actors to systems of innovation

15. From market failure to system failure

16. From one to two "faces" of R\&D

17. From "Model 1" to Model 2"

18. From single technology to multiple-technology firms

19. From national to multi-level systems of innovation

20. From closed to open innovation

\section{b) Twenty challenges for "Innovation Studies" (Martin, 2015)}

1. From visible innovation to "dark innovation"

2. From innovation in manufacturing to innovation in services

3. From boy's toys to "women's liberation"

4. From national and regional to global systems of innovation

5. From innovation for economic productivity to innovation for sustainability ("green innovation")

6. From innovation for economic growth to innovation for sustainable development

7. From risky innovation to socially responsible innovation

8. From innovation for wealth creation to innovation for well-being (or from "more is better" to "enough is enough")

9. From "winner take all" to "fairness for all"

10. From government as fixer of failures to the entrepreneurial state

11. From fait-based policy (and policy-based evidence) to evidence-based policy?

12. Balancing the intrinsic tensions between intellectual property and open source

13. Balancing the intrinsic tensions between exploration and exploitation

14. Balancing the intrinsic tensions between closed and open innovation

15. Balancing the intrinsic tensions between competition and cooperation

16. Pricking academic bubbles

17. Identifying the causes of the current economic crisis

18. Avoiding disciplinary sclerosis

19. Helping to generate a new paradigm for economics - from Ptolemaic economics to???

20. Maintaining our research integrity, sense of morality and collegiality 